\title{
Eciton Army Ants-Umbrella Species for Conservation in Neotropical Forests
}

\author{
Sílvia Pérez-Espona ${ }^{1,2}$
}

1 Royal (Dick) School of Veterinary Studies, The University of Edinburgh, Roslin, Scotland EH25 9RG, UK; silvia.perez-espona@ed.ac.uk

2 The Roslin Institute, The University of Edinburgh, Roslin, Scotland EH25 9RG, UK

Citation: Pérez-Espona, S. Eciton Army Ants-Umbrella Species for Conservation in Neotropical Forests. Diversity 2021, 13, 136. https:// doi.org/10.3390/d13030136

Academic Editors: Alan N. Andersen and Luc Legal

Received: 14 February 2021

Accepted: 13 March 2021

Published: 22 March 2021

Publisher's Note: MDPI stays neutral with regard to jurisdictional claims in published maps and institutional affiliations.

Copyright: (C) 2021 by the author. Licensee MDPI, Basel, Switzerland. This article is an open access article distributed under the terms and conditions of the Creative Commons Attribution (CC BY) license (https:// creativecommons.org/licenses/by/ $4.0 /)$.

\begin{abstract}
Identification of priority areas for conservation is crucial for the maintenance and protection of biodiversity, particularly in tropical forests where biodiversity continues to be lost at alarming rates. Surveys and research on umbrella species can provide efficient and effective approaches to identify potential areas for conservation at small geographical scales. Army ants of the genus Eciton are keystone species in neotropical forests due to their major role as top predators and due to the numerous vertebrate- and invertebrate associated species that depend upon their colonies for survival. These associates range from the iconic army ant-following birds to a wide range of arthropod groups, some of which have evolved intricate morphological, behavioural and/or chemical strategies to conceal their presence and integrate into the colony life. Furthermore, Eciton colonies require large forested areas that support a diverse leaf litter prey community and several field-based and genetic studies have demonstrated the negative consequences of forest fragmentation for the long-term maintenance of these colonies. Therefore, Eciton species will not only act as umbrella for their associates but also for many other species in neotropical forests, in particular for those that require a large extent of forest. This review summarises past and recent accounts of the main taxonomic groups found associated with Eciton colonies, as well research assessing the impact of forest fragmentation on this army ant, to encourage the adoption of Eciton army ants as umbrella species for the identification of priority areas for conservation and assessments of the effect of disturbance in neotropical forests.
\end{abstract}

Keywords: antbird; army ant; biodiversity; biological indicator; conservation; deforestation; habitat fragmentation; myrmecophiles; mimicry; species interactions; tropics

\section{Introduction}

Disturbance as a consequence of anthropogenic activities continues to be a major driver of biodiversity loss [1-4] and it negatively impacts ecosystems functioning and ecosystem services [5-7]. In tropical forests, anthropogenically-caused disturbance as a result of logging, land clearance for agriculture and hunting [8,9] are ongoing threats to biodiversity and ecosystem function $[10,11]$. Therefore, to devise effective conservation actions and sustainable management of tropical forests resources, it is important to determine and predict the effects of anthropogenic disturbance in these biodiversity-rich areas [12,13]. However, the assessment of anthropogenic disturbance on biodiversity in tropical forests is challenging due to the lack of knowledge on a large number of taxa in these areas, including those not yet discovered and described [14], and the limited budgets and timeframes for conducting biodiversity assessments [15]. These challenges have partly been overcome by conducting surveys of a reduced number of well-known and identifiable taxonomic groups (or species) that can act as biological indicators to determine the level or magnitude of anthropogenic disturbance [16-19], although not without caveats [20-23].

Insects represent a large part of the biodiversity found in tropical forests and play a central role in ecosystem function and services [24,25]. Owing to their short life cycles and 
habitat disturbance sensitivity, insects are considered suitable biological indicators for monitoring the effects of fragmentation and other environmental changes on biodiversity $[26,27]$ as well as for monitoring the sustainable use of tropical forests [28]. Furthermore, insects are also used as biodiversity indicators, with their diversity used as surrogate information for species richness estimates in a given area or to identify priority areas for conservation [22]. Among insects, ants comprise the largest fraction of animal biomass in the tropics and are frequently used as environmental, ecological and biodiversity indicators [29-33]. In the Neotropics, army ants are dominant components in forests and as top predators of arthropod communities play a major role in leaf litter community structure [34-36]. The most conspicuous army ants in neotropical forests are those within the genus Eciton, due to their large hunting raids and the numerous invertebrate and vertebrate species associated with them that exploit the different environments and conditions provided by these ants colony life [29,36-38]. Furthermore, Eciton colonies are particularly sensitive to landscape fragmentation and deforestation, with large areas of continuous forests required for their long-term survival [34,39].

Monitoring of biodiversity and ecosystems function is essential for the maintenance and sustainable use of neotropical forests $[28,40]$. Biodiversity conservation through area protection or other effective area-based conservation approaches requires the identification of areas of high biodiversity, high irreplaceability, large intact habitats with a high degree ecological integrity and/or high vulnerability due to the impact of anthropogenic activities [12,13]. Surveys assessing the presence and abundance of Eciton colonies in a particular area could provide additional information on the selection of conservation areas in neotropical forests. Although Eciton army ants have been used as biodiversity or habitat integrity indicators [41], they have not yet been implicitly considered as umbrella species for biodiversity conservation in neotropical forests or considered as biological indicators to assess the impacts of forest disturbance.

This review aims to encourage the adoption of Eciton army ants as potential umbrella species for neotropical forest biodiversity conservation. To this end, I build on previous detailed accounts of Eciton colony associates [37,38,42] to provide further insights derived from research conducted in the last decade, including the significant contributions of genetic and genomic studies to our understanding on the relationship of some of these associates with their Eciton hosts. Furthermore, this review also summarises research on the effect of deforestation or other land-use changes on Eciton colonies, to illustrate the potential use of these army ants in applied research assessing the impact of disturbance or success of restoration projects in neotropical forests.

\section{Eciton Army Ants}

Several ant genera within the subfamily Dorylinae are referred to as army ants, with the genera Cheliomyrmex, Eciton, Labidus, Neivamyrmex and Nomamyrmex forming a monophyletic group and found in tropical and subtropical regions in the American continent $[43,44]$. Army ants are characterised by presenting the "army ant syndrome" which includes the evolution of behavioural and reproductive traits that have allowed them to be key predators in neotropical forests. This suite of traits includes obligate collective foraging, nomadic lifestyle, and highly specialised queens which are characterised by being wingless and having large expanding abdomens capable of lying thousands of eggs [38,45-47]. Colony founding of Eciton army ants is by fission. When colonies attain a large size, a sexual brood is produced, containing a small number of new queens and hundreds of males. The parental colony will then divide into two daughter colonies, one of them headed by a new queen and the other one headed either by the old queen or another of the new queens $[36,48]$. Initial phylogenetic analyses based on data derived from three nuclear genes, one mitochondrial gene, and morphological analyses, suggested that the evolution of the "army ant syndrome" in army ants species in the Americas and AfroEurasia was as a result of inheritance of these traits from a unique Gondwanan common ancestor [46]. However, a recent comprehensive phylogenomic study based on 2,166 loci 
has indicated multiple origins for the "army ant syndrome" in different continents [44]; therefore, supporting initial views of convergent evolution of this syndrome [38].

The genus is distributed from Mexico to Argentina [38], with 12 Eciton species, and several subspecies, described [49]. Genomic analyses using a large number of loci $(>4,000,000)$ for 146 specimens, collected from a wide distribution range and representing those nine species for which workers and queens are known, strongly supported interspecific relationships congruent with taxonomic classifications [50]. However, further taxonomic revisions are required to delimit species and subspecies boundaries. For example, a phylogeographic study based on mitochondrial DNA sequences indicated that genetic divergence of E. burchellii foreli and E. b. parvispinum colonies was higher than between other morphologically described species [51].

Foraging and emigration of Eciton army ants takes place above ground [36,52]. The species E. burchellii and E. hamatum are considered truly epigaeic, as they bivouac above ground. Other Eciton species such as E. mexicanum, E. vagans and E. dulcium tend to bivouac in more sheltered and darker places, inside or beneath logs, or in underground erosion chambers [36]. In these more hipogaeic species, raids and emigration columns can take place underground but only for short distances and when near the bivouac [53]. Knowledge on Eciton army ants is primarily based on research focused on E. burchellii and to less extent on E. hamatum, as these two species are the most epigaeic diurnal Eciton species. Most Eciton species are column raiders (e.g. E. hamatum, E. vagans), with hunting taking place by ants moving initially in narrow columns that later divide into several diverging branches. The size of the raid varies among species, from sparse raid front such as those in Eciton dulcium, often narrower than $2 \mathrm{~m}$, to swarm fronts wider than $5 \mathrm{~m}$ in in the swarm raider E. burchellii $[38,53,54]$.

A large-scale survey conducted at La Selva Biological Station (Costa Rica) examining the diets of sympatric neotropical army ants, including the species E. burchellii, E. dulcium, E. hamatum, E. lucanoides, E. mexicanum and E. vagans revealed high specialisation and small spatio-temporal niche overlap [55]. Using DNA barcoding to identify ant prey to the species level revealed differences in raiding preferences, with E. dulcium and E. mexicanum preferentially raiding ground-nesting ants and E. hamatum and E. burchellii arboreal-nesting ants. Furthermore, E. hamatum and E. burchellii colonies were found to have more diurnal raids whereas most of the other Eciton species had primarily nocturnal raids [55].

All Eciton species are predominantly predators of other ants (mainly their brood) although they specialise on different ant genera. E. hamatum predominantly preys on the brood of Acromyrmex leaf-cutting ants, E. dulcium on Pachycondyla and Odontomachus ants, and E. burchellii on Camponotus ants [14-20]. Although the diet of E. burchellii is more varied and includes a diverse range of non-ant litter arthropods, in particular the brood of other social insects [56-61], this non-ant component of the prey might be comparatively low [55]. The large colony size of Eciton species, with estimates ranging from 150,000 to 500,000 workers in E. hamatum and 500,000 to 2 million workers in E. burchellii [38], and the relatively large body size of of some of the workers imply high colony-energy demands [62]. Colonies of Eciton army ants have a nomadic-statary cycle, with periods of in which the bivouac (temporary nest) remains in a fixed location where the queen lays thousands of eggs [63]. During this period, the workers hunt prey locally in a regular manner. The statary phase is followed by a nomadic phase coinciding with the eggs hatching into larvae and, during this phase, the colony emigrates daily after the raids over the period of 2-3 weeks [36,64]. In the most studied species, E. burchellii, colonies concentrate their raids on invertebrate-rich forest patches [65] and a colony could capture $c$. 30,000 items of prey in a single day [66]. The nomadic-statary cycle of Eciton colonies is interpreted as an adaptation to avoid prey depletion by promoting population recovery of their prey [56]. The pattern of raids, as part of the nomadic lifestyle of Eciton army ants, therefore, exerts top-down regulation of leaf litter arthropod communities and creates a mosaic of habitat patches at different ecological succession stages which increases local species diversity $[35,65,67]$. 


\section{Associates of Eciton Army Ants}

Eciton army ants play an important role for the maintenance of biodiversity in neotropical forests not only due to the mosaic habitat that they create as top predators but also due to the hundreds of associate species that depend on these army ants for their survival $[36,37,68,69]$. The next sections will provide an overview of the main taxonomic groups found with Eciton army ant colonies, with a particular focus on arthropods, as this is the most abundant taxonomic group of associates (Figure 1).

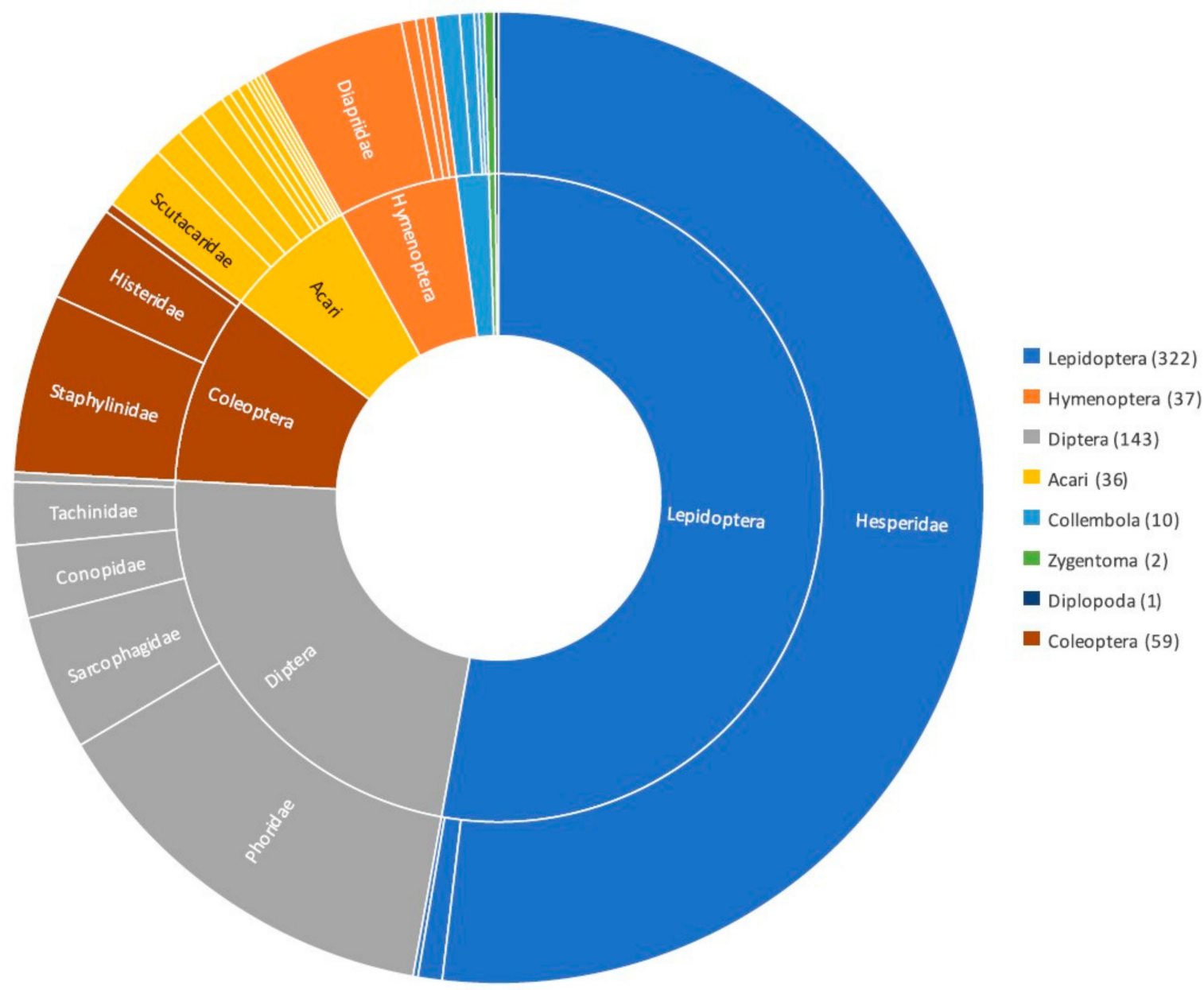

Figure 1. Diagram illustrating the different arthropod taxonomic groups found as associates of Eciton army ants. Numbers in brackets indicated number of species reported as Eciton burchellii associates; data from Rettenmeyer [69]. See Table S2 for further details of families with lower representation within each of the main arthropod taxonomic groups.

\subsection{Birds}

The majority of studies on associates of Eciton army ants have been conducted on the iconic antbirds (Table S1). Army ants provide important foraging resources for antbirds as these primarily feed on arthropods flushed during the ant raids [36,70]. The most commonly reported army ant following birds are within the families Cuculidae, Formicariidae, Furnariidae, Thamnophilidae and Thraupidae, although species from other bird families can also be found at army ant raids [68]; see Table S1. Phylogenetic studies of the Thamnophilidae have revealed that this army ant-following specialisation has evolved three times in this bird family and that this specialization is ancient, with an origin in the late Miocene [71]. Furthermore, the most likely evolution progression of specialisation has been indicated to be from occasional to regular visits, to an obligate association with the army ants (Figure 2). 


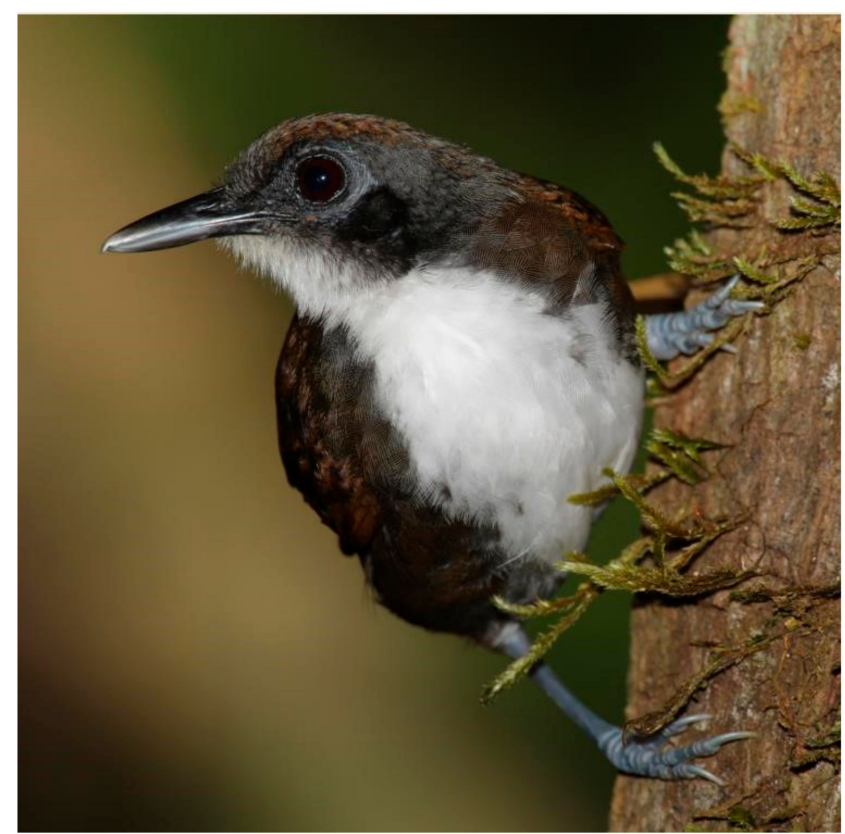

Figure 2. The Bicolored Antbird (Gymnopithys leucaspis, family Thamnophilidae) is an obligate army ant follower of Eciton burchellii colonies. Birds of this species are found at high frequencies at swarms and check bivouac sites. Photo taken at Parque Nacional Darién, Panama (Matt Deres at English Wikipedia, CC BY 3.0).

Antbirds are more commonly found with epigaeic diurnal swarm raid-forming army ants such as E. burchellii and Labidus praedator $[68,69]$. Although other Eciton species characterised by having column raids, straggling swarm or semi-nocturnal habits might not be important resources for diurnal ant-following birds, reports indicate that antbirds can also be found associated with column-raid army ants when the raids are spread [72]. Antbirds are also occasionally reported with straggling swarms such as those of E. rapax [73] and the mainly nocturnal species E. mexicanum [72] and E. vagans [74]. Screech owls (Otus spp.) have also been reported to follow nocturnal raiding army ants in some instances [68].

In addition to the flushed arthropods during army ant raids, antbirds have also been reported to benefit by capturing larger prey such as Anolis lizards [75]. The capture of fleeing snakes by Collared forest falcons (Micrastur semitorquatus) during E. burchellii parvispininum raids has also recently been reported [76]. The association of antbirds with army ants range from occasional visitors to obligate attendants of the raids [68,77-79], see Table S1. Numerous antbirds appear after an army ant raid starts and will then follow the hunting swarm as it advances. Obligate species are likely to track the location of the army ant colonies and some antbirds have been reported to visit statary bivouacs, potentially as a way to monitor colony activity $[68,80]$. Antbirds are considered parasites of the army ants, as exclusion experiments have indicated a detrimental effect of the antbird foraging on the success rate of prey capturing by ants [81]. Although some field observations [82,83] and gut content analyses [84] have reported the consumption of army ants by antbirds, it is not yet clear if consumption of army ants by antbirds can be intentional in some instances or if this consumption is accidental as most reports indicate [68].

\subsection{Other Vertebrates}

Observations of mammals associated with Eciton army ants are limited to marmosets, with five species having been reported to take prey flushed by Eciton burchellii in Brasil $[85,86]$. Callithrix humelifer and C. kuhli are the species more frequently reported in E. burchellii raids, with $C$. humelifer observed to spend several hours picking prey including that being carried by the ants [85]. Other vertebrate species such as the toad Bufo marinus, 
teid lizards of the genus Ameiva and Kentropyx, and the iguanid Anolis frenatus have also been reported to found associated with Eciton army ant raids [68].

\subsection{Mites}

The most numerous associates of Eciton colonies, in terms of number of individuals, are mites. It is estimated that myrmecophilous mites found in colonies of army ants within the tribe Ecitonini can be in a ratio > 100:1 to other myrmecophilous arthropods and c. 1:100 to ants in the colony, although in some colonies the ratio can be as high as 1:4 [37]. At least 126 species belonging to 33 different genera of mites have been described in association with army ants in the tribe Ecitonini, 21 of the genera found to be unique to them [87], and 41 taxa found in E. burchellii colonies [69]. However, further research is needed to determine if some of these taxa are associated with the army ants or their prey [87].

Some of the mites associated with Eciton species can be found either in refuse deposits or middens taking advantage of this food resource (refuse, discarded prey, ant corpses or fungi). However, those thought to be more intimately associated with the army ants are found in the bivouacs and/or emigrating columns [37,69]. Although the nature of the association of the mite taxa with the army ants is yet not well understood, this can potentially be parasitic, mutualistic, phoretic or considered as predators of other taxa visiting the middens [88]. Most of the mite taxa more closely associated with Eciton colonies are phoretic, i.e. using the ants as transport agents at least for one stage of their life cycle dispersal, with the phoretic relationship being either facultative or obligatory [38]. Life cycles for mites associated with army ants remain largely unknown but it is likely that they are synchronised with the emigration intervals in Eciton host colonies [38]. Phoretic mites have adaptations to be able to ride along with the emigration columns or attach to different parts of the queen, males, different worker castes, and larvae [37,89]. Phoretic mites have also evolved strategies to hitchhike on the ants, such as cuticular ridges on the lateral body flanges developed on adult Antennequesoma mites allowing them to attach to Eciton workers' antennae or legs [89], or Planodiscus mites that their body is sculptured to resemble structures of their Eciton hosts to attach to their legs [88,90,91]. Some mites associated with Eciton army ants are ectoparasites of brood or adult ants, and feed on the host's hemolymph or integumental secretions, with some species having evolved striking adaptations to attach on different body parts of workers and integrate into the colony $[37,87,88]$. An example of ectoparasitic mites is Macrocheles rettenmeyeri which is found attached on the membrane of hind legs' pulvilli of Eciton dulcium workers [92]. The mite's curve hind leg resembles the ant's tarsal claws and, therefore, assumes the function of this body part when the ants hang to one another forming a bivouac [88]. Rettenmeyerius carli is another example of ectoparasitic mite, in this case, found attached to the mouthparts of majors [37].

The effects of parasitic mites on Eciton colonies are unknown. Inspection of E. burchellii workers collected during raid columns from 20 colonies in Barro Colorado (Panama) indicated that mite species diversity was high, with a greater number of mites observed in ants collected in raids during the statary phase [93]. Mite prevalence was of c. 5\% (from a total of 3146 ants analysed), with infection found to be higher in larger workers (majors and submajors), and R. carli the most commonly found mite on E. burchellii workers [93]. However, it is important to highlight that workers in raid columns represent only onethird of the colony [66] and, therefore, prevalence and infection rates might differ in army ants staying in the bivouac [93]. According to mite groups feeding preference classifications $[87,94]$, most of the mites observed in this study were suggested to be relatively harmless for the ants (e.g. fungivore, bacterivore), with only 2 out of the 31 taxa classified with confidence as parasitic (R. carli, and an unknown taxon within the family Circocyllibanidae).

\subsection{Flies}

Flies are the second most numerous associates in terms of individuals reported on army ant Eciton colonies, with flies within the family Phoridae being the most abundant. 
Phorid (or scuttle) flies are found in swarm raids, ant columns, bivouacs and refuse deposits $[37,69]$. In addition to phorid flies, blowflies (Calliphoridae), thick-headed flies (Conopidae), flesh flies (Sarcophagidae) and tachinid flies (Tachinidae) are also found during Eciton raids, in particular in the front or in advance of the swarm fronts. Flies found in Eciton raids either hover constantly over the raid or rest on objects with the aim to parasitise insects flashed during the raids. These flies avoid being near the army ant columns or swarms and, similar to other associates, can be either facultative or obligatory [95]. Frequently reported parasitic flies are species within the genera Androeurops, Apocephalus or Stylogaster or Calodexia $[69,95,96]$. Different species of Androeurops have been reported attacking crickets and cockroaches flushed during E. hamatum and E. burchellii raids [37,96]. These flies might be attracted to Eciton raids when they detect distress pheromones released from the ants' victims such as found for the phorid Apocephalus paraponerae that parasitises the bullet ant Paraponera clavata [97]. Phorid flies of the genus Cremersia and Dacnophora have been shown to parasitise non-Eciton neotropical army ants (Neivamyrmex, Nomamyrmex, and Labidus) but there are no records of parasitic flies of Eciton army ants [95], although other phorid flies found near the raids might parasitise some Eciton associates [95]. In addition to those flies found over or near Eciton raids, species within the families Phoridae, Muscidae and Sarcophagidae are commonly found in ants refuse deposits and might be flying between bivouacs to locate these food resources [37].

\subsection{Beetles}

A diversity range of beetles, in particular of the those belonging to the families Staphylinidae and Histeridae, are found associated with Eciton colonies either in refuse deposits or in emigration columns [37]. These beetles range from generalists and are found with more than one genus of army ant, e.g. species within the genus Alloiodites [37], to host-specific and only found with colonies of a single Eciton species, e.g. Ecitophya, Ecitomorpha [51]. Some beetles are found in refuse deposits feeding either on dead workers or booty refuse, with reports of flying between bivouacs (e.g. Ecitophora, Omalodes) and/or running in emigration columns (e.g. Mesynodites, Phelister). Staphylinidae beetles are common in Eciton emigration columns, most frequently located at the edges of the column. Beetles found in emigration columns do not attack the ants, except for some predators such as Tetradonia terminalis which predates on adult workers of E. burchellii, E. hamatum and E. lucanoides [37,98]. Integrative taxonomic studies, including DNA barcoding approaches, on Eciton colonies in La Selva Biological Station (Costa Rica), identified five Tetradonia species, including two novel species. Host specificity varied among species, with the generalist T. laticeps parasitising six species of Eciton to the specialised T. lizonae mainly associated with E. hamatum colonies [99].

During the procession of associates following Eciton emigration columns, the number of beetles is particularly abundant when the brood is carried away from the bivouac. At this phase of the emigration is when the diversity of beetles more intimately associated with Eciton colonies can be observed, such as species of the genera Euxinister, Vatesus, Cephaloplectus, Limulodes, Ecitophya and Ecitomorpha [37,100,101]. Among this array of Eciton-following beetles, a number of histerid and staphylinid beetles have evolved morphological, chemical and/or behavioural strategies for further integration in the colony. Some species have evolved adaptations to enable them to ride on the different castes. For example, Pulvinister nevermannii has been observed riding under the major heads of E. hamatum [42,102], Limulodes species riding on queens, and some histerids observed riding on males when present in the colony. Some beetle species are found riding on different worker castes, such as Euxenister wheeleri found with E. hamatum emigration columns, as well as pupae and larvae carried by workers such as Euxenister caroli found in emigration columns of E. burchellii [37,42,102,103].

Two genera of staphylinids, Ecitomorpha and Ecitophya (Figure 3) are often found in raids, as well as emigration columns of Eciton army ants. These beetles are highly specialised to the nomadic life of Eciton colonies and mimic their media workers [104]. 
These two genera of staphilinids have evolved similar body modifications to moderately resemble their host, including their colouration [104-106]. The presence of Ecitomorpha and Ecitophya is rare on Eciton colonies, with an estimate presence of less than one beetle per 1000 workers. These beetles are found in raiding columns feeding on dropped prey or booty catches, and, hence, these beetles are considered hunting guests of the army ants [106]. Ecitomorpha and Ecitophya are adapted to the nomadic life of Eciton colonies and are also found in emigration columns, walking in the centre of the column or riding on ant pupae or prey captured by the ants $[105,106]$. Early taxonomic work on the genera Ecitomorpha and Ecitophya indicated single host-specificity due to their parallel colouration to that of their host $[107,108]$. However, later taxonomic treatments lumped several species into a single one, due to the difficulties in finding consistent morphological characters, including colouration, to separate species $[104,106]$. Using an evolutionary and population genetics framework, analyses of mitochondrial DNA sequences of Eciton hosts and their associated Ecitomorpha and Ecitophya, collected in different areas in east and west Panama, revealed that the speciation pattern of these two myrmecophiles was congruent with specialization to a single species (or subspecies) of Eciton host [51]. Molecular clock analyses conducted in this study suggested that Eciton host diversification pre-dated that of their hunting guests, and that Ecitophya have been associated with Eciton for a longer period of evolutionary time than Ecitomorpha [51]. Furthermore, patterns of diversification of the two hunting guests were also consistent across broad geographical areas but not at small geographical scales, with evidence of gene flow between colonies even across large water features [51]. The specialisation of Ecitophya and Ecitomorpha with their Eciton hosts has also been further confirmed by analyses of cuticular hydrocarbons (CHCs) and behavioural analyses of individuals collected at La Selva Biological Station in Costa Rica [109]. In contrast, similar analyses in the staphylinid ant predator Tetradonia indicated that as a generalist, their chemical profile was more dissimilar to their Eciton hosts, compared to that of the specialists Ecitophya and Ecitomorpha [109].

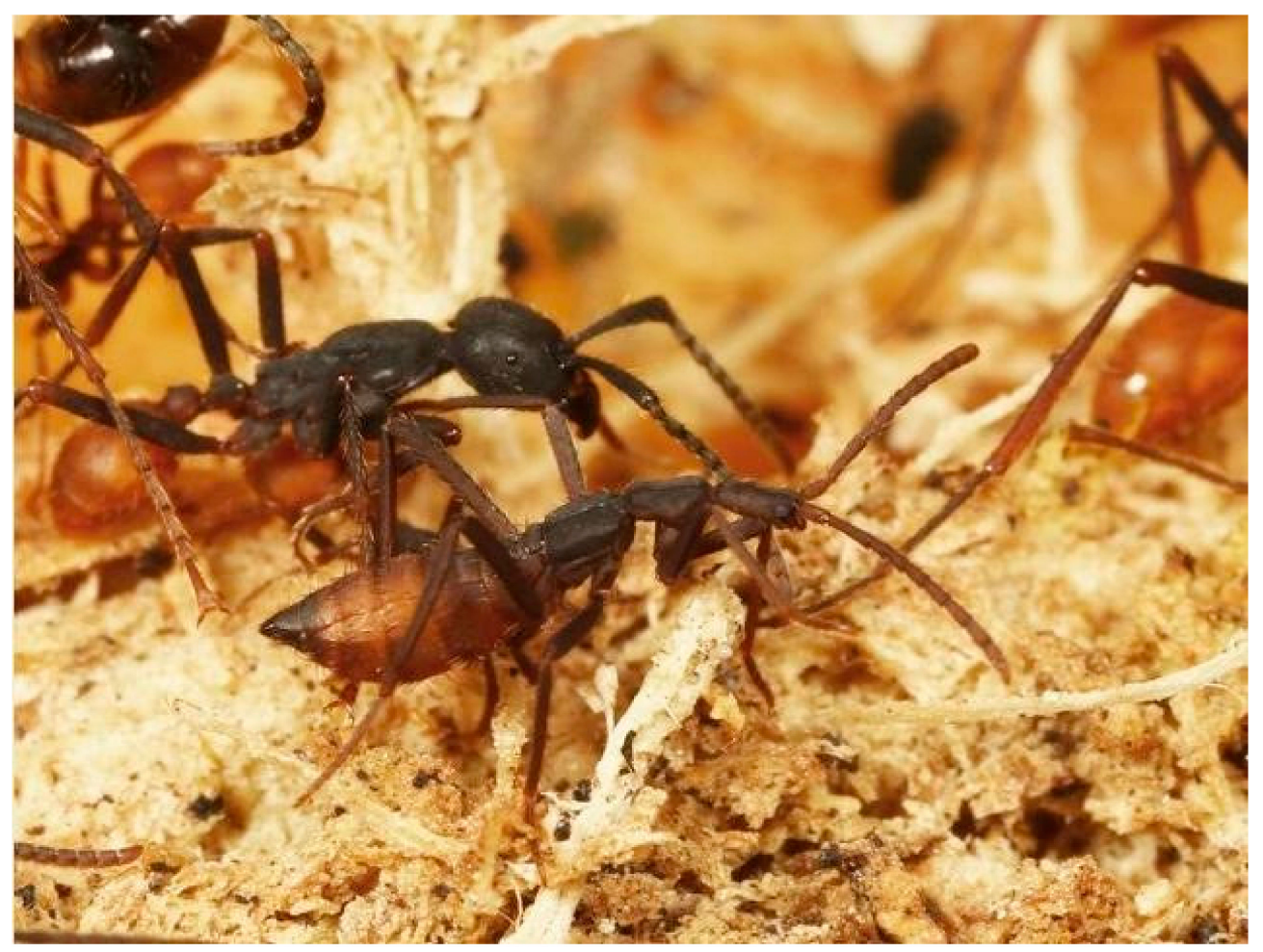

Figure 3. The rove beetle Ecitophya simulans (family Staphylinidae) moderately mimics of Eciton burchellii media workers and is considered a hunting guest. Photo of Ecitophya simulans next to an Eciton burchellii foreli media worker (Taku Shimada). 
Beetles of the genus Vatesus (Staphylinidae) are also considered to be intimately associated with Eciton army ants. These large and conspicuous limuloid (horseshoe crabshaped) beetles, and in particular the species V. clypeatus, have been observed in E. burchellii, E. hamatum, E. vagans, E. dulcium and possibly E. mexicanum colonies $[42,100,110]$. The life cycle of Vatesus beetles was suspected to be tightly linked to their Eciton hosts, with reproduction and larval development observed to be synchronised to the reproduction and nomadic cycles of their Eciton hosts during field studies $[37,101,110]$. The full life cycle of Vatesus, however, was only reconstructed in a relatively recent study using DNA barcoding approaches in which high Eciton host-specificity was confirmed and cryptic diversity within the species V. clypeatus identified [111].

\subsection{Other Arthropods}

Springtails (Collembola) are abundant in refuse deposits and are represented by a large number of species that might primarily feed on fungi or mould [37,42]. Some species are considered myrmecophilous and also found within the bivouac, in particular those belonging to the subfamilies Cyphoderinae and Paraollinae. The most common myrmecophilous springtails found in Eciton colonies belong to the genus Cyphoda [37], and two species of Cyphoderus have also been reported from E. burchellii and E. hamatum refuse deposits and suggested as myrmecophiles. However, a large number of springtail taxa found in bivouacs and refuse deposits of E. burchellii remain to be identified [37,69].

Millipedes (Diplopoda) of the genera Calymmodesma and Rettenmeyeria have been reported in Labidus and Nomamyrmex army ant columns but not in Eciton [42,112,113]. Only one species, Prionodesmus fulgens, has been reported near bivouac detritus of E. burchellii colonies [69].

Silverfish (Zygentoma; previously Thysanura) have been observed in bivouacs, emigration and raid columns of Eciton species, in particular species within the genus Trichatelura [37]. The species T. manni and T. borgmeiri are frequently observed running in the centre of the emigration columns when brood is carried from the bivouac, or during nocturnal raid columns where T. manni has been also observed to ride on large larvae or booty carried by the ants $[37,42]$. Trichatelura manni has been found associated with different Eciton species and observed cleaning and riding on the queens of E. vagans and E. dulcium crassinode [42]. Observations of T. manni in the laboratory conditions confirmed this species as strigilator, feeding on secretions or particles from surfaces of army ant adults, larvae and booty [37,52].

Small wasps of the family Diapriidae are found as associates in Eciton colonies [37,114,115], with 17 Diapriidae genera found associated with Eciton burchellii colonies [69]. Similar to the mimicry observed in myrmecophilous staphylinids, some of these parasitic wasps have also evolved strategies to integrate into Eciton colonies by modifying its form and colour to resemble their Eciton host media workers. For example, Mimopria ecitophila mimics media workers of E. hamatum and it is found in raid and emigration columns of this army ant [42]. These army antmimicking wasps are frequently found running in the ant columns and are probably parasites of the army ants or some or their guests $[37,42,103,114]$. Other Hymenoptera families have also been observed over or near E. burchellii colonies or refuse deposits, including other parasitic wasp families such as Scelionidae, Proctotrupidae, and Pompilidae; the latter called spider wasps and suggested to follow the army ant swarms to find spider victims to parasitise [69].

The latest survey of E. burchellii associates conducted by Rettemeyer et al. [69] indicated that over 300 butterfly (Lepidoptera) species within the families Hesperiidae, Nymphalidae and Papilionidae were sampled on bird droppings and/or using lures at swarm raids of E. burchellii. These butterflies might extract uric acid or partly digested proteins from the bird droppings to be used for egg production [42]. Early field observations of these butterflies, in particular skippers, suggested that Eciton colony odours during the raids could resemble male mating pheromones and, therefore, explain the presence of only female skippers $[116,117]$. However, the recording of male skippers in E. burchellii swarm raids casted doubt on the previous hypothesis [118]. A more plausible explanation is that skippers, such as those within the genus Mechanitis, are attracted to E. burchellii swarm 
raid odours as a method of colony detection where they can search for the antbird droppings [119-121]. After observations of the species Mechanitis polymnia ishtmia, M. lysimmia doryssus, and Melinea lilis imitata feeding on droppings from antbirds, in particular from the family Formicariidae, during E. burchellii raids, led to coining the term antbutterflies to highlight the close association of these butterflies with this army ant colonies [120]. In addition to the presence of butterflies in Eciton raids, microlepidoptera caterpillars have also been reported from refuse deposits [37].

\subsection{Microbes}

The application of DNA metabarcoding approaches has also facilitated recent studies assessing the gut microbiota of army ants. The first initial survey of army ants gut microbiota showed that some ant-specific bacteria clades (e.g. Entomoplasmatales) were shared between three species of neotropical army ants, E. burchellii, Nomamyrmex hartigii, and Cheliomyrmex sp. [122]. This study also found that these bacteria were likely to be associated with the predatory lifestyle of the army ants; although no essential nutritional benefits could be attributed to the presence of these bacteria [122]. A more recent study survey of gut microbiota in army ants including samples from three army ant genera (Eciton, Labidus, and Nomamyrmex) further confirmed a degree of specialisation of certain gut microbial communities in army ants, with the most abundant microbes assigned to Unclassified Firmicutes and Unclassified Entomoplasmatales [123]. Further analyses of these data indicated that gut microbiota variation was found at different levels, between and within species of E. burchellii and L. praedator, as well as between sympatric colonies E. burchellii in Monteverde (Costa Rica), Henri Pittier National Park (Venezuela), and Cocahoatan (Mexico). Variation of gut microbiota composition found in army ants would agree with studies indicating that landscape and local environment can shape gut microbiota in wild insect populations, therefore, explaining geographical variation on microbial profiles $[124,125]$. One intrinsic challenge faced in DNA metabarcoding of gut contents is our inability to distinguish signatures (in this case DNA sequences) derived from the target species and those of their prey [126]. Therefore, future analyses would benefit from a comparison of gut microbiota of Eciton host to those of their potential prey.

\subsection{Further Research on Eciton Associates}

Although a multitude of vertebrate and invertebrate species associated with Eciton army ants have been described, substantial research is still required to identify many of the arthropod taxa collected or observed in previous studies [69]. Interdisciplinary integrative taxonomy-focused projects would be crucial to advance the identification and classification of these taxa, the discovery of new species, and elucidation of host specificity $[99,127]$. Furthermore, reports and studies of associates of Eciton army ants have primarily focused on E. burchellii. Therefore, further research on associates of other Eciton species with different lifestyles, foraging patterns and behaviours (e.g. hypogaeic lifestyle, nocturnal raids) is likely to identify an additional suite of vertebrate and invertebrate associate taxa to those already reported with E. burchellii. Beyond research on different Eciton species, there is also a need for studies to cover wider geographical areas, as the genus Eciton has a wide distribution, from Mexico to Argentina, but studies on associates of these army ants have mainly been restricted to Costa Rica and Panama to date. The creation of a network of researchers ensuring the participation and coordination of research projects by local researchers would facilitate the collection of samples, funding and collaboration needed to increase our understanding of Eciton army ants and their associates throughout their distribution range.

\section{Deforestation and Eciton Army Ants}

Deforestation and habitat fragmentation are predicted to have negative effects in particular on species at higher trophic levels, higher mobility, greater ecological specialization and representative early diverging lineages [128]. The effects of habitat fragmentation, 
therefore, are expected to be more accentuated in top predators such as army ants, with studies on E. burchellii indicating negative long-term responses to forest fragmentation [129]. Eciton army ants require large forested areas to obtain large amounts of leaf litter prey and maintain their large nomadic colonies, as well as to shelter from higher temperatures encountered in open areas [60,63,130-132]; therefore, making them particularly sensitive to landscape fragmentation and deforestation [34,39]. Simulation studies based on E. burchellii colonies on Barro Colorado Island (Panama) estimated that areas of at least 30 ha of continuous forested would be needed to support a single colony of this army ant [39]. This critical area might differ between geographical areas as field-based studies of E. burchellii colonies in Mato Grosso (South West Amazonia, Brazil) found that colonies of this species emigrate less frequently than in Barro Colorado Island, possibly due to a larger density of prey in this area [133]. However, other studies on E. burchellii colonies have indicated that even when large areas of forest remain after fragmentation, the long-term persistence of colonies is not guaranteed if these patches are not connected by suitable corridors $[34,39,56,131,134]$.

The maintenance and expansion of traditional agrosystems such as shaded coffee and cocoa plantations are considered realistic management actions to address current environmental and socio-economic challenges in neotropical areas [135]. The presence of Eciton colonies has been reported in shaded coffee and cocoa plantations, as these habitats provide prey as well as bivouac resources [136-139]. However, the use of shaded coffee and cocoa plantations by Eciton colonies might be only temporary and dependent on the availability of non-modified forested areas nearby $[136,139,140]$. A landscape genetics study of E. burchellii colonies in Panama gave further support to the importance of maintaining mature forested areas [141]. This study revealed that deforestation is a major gene flow barrier for E. burchellii foreli colonies. In contrast, mature forests were identified as gene flow facilitators. Other forest types, including shaded coffee plantations, were found to act as gene flow facilitators but only when these were located nearby mature forests [141]. The negative effect of deforestation in E. burchellii gene flow was also demonstrated in a subsequent landscape genetics study in Costa Rica that revealed that queen relatedness was correlated with land cover, further highlighting the need to maintain connectivity between colonies [142]. Gene flow between colonies was assumed to be primarily by the large winged males when they emerge and fly in large numbers from their colonies in search of mates; Eciton queens are wingless and dispersal, therefore, is entirely pedestrian [48]. This male-biased dispersal has also been indicated by genetic studies comparing maternallyinherited mtDNA sequences and biparentally-inherited microsatellite genotyping data from E. burchellii colonies [141,143,144]. However, a recent study analysing population structure of E. b. parvispinum across years using microsatellite markers indicated that due to the nomadic lifestyle of these army ants, queen dispersal significantly contributes to gene flow and in some instances exceeds that of males [145].

The creation or protection of forested corridors between neighbouring forested fragments has been suggested as possible management actions to facilitate connectivity and longer-term persistence of $E$. burchellii colonies, as thermal ecology studies indicated that high temperatures in open pastures between fragments could prevent the ants to leave their forest patches [131]. These corridors would not only be beneficial to guarantee gene flow between colonies by facilitating queen and colony pedestrian dispersal but also the dispersal of winged males. Although due their nocturnal behaviour, Eciton males are less likely to be affected by high temperatures in open areas between forest fragments, flying over open areas increases the risk of predation by nocturnal insectivorous vertebrates [146,147]. Therefore, suitable forest corridors between fragmented areas would facilitate dispersal, and subsequent gene flow, via maternal and paternal lines.

Foraging rates of diurnal epigaeic army ants such E. burchellii are lower in open areas compared to forested areas, in particular at lower elevations where these ants might be at their upper limit thermal tolerance threshold [131,132]. Although E. burchellii colonies are frequently reported to cross open areas, use remnant forest fragments [131] and heavily overgrown abandoned pastureland [148], even brief exposure to high temperatures can 
lead to mortality of their workers [131]. Therefore, movement of colonies between forest fragments might be conditioned by temperature in the environment and vegetation characteristics of the less hospitable matrix between the fragments [131]. The crossing of open areas is feasible during cloudy days or in areas where scattered trees and shrubs can provide shade during the passage [131]. However, mortality among workers during these incursions has been observed after cloud clearing during hottest hours of the day (Pérez-Espona, pers. comm.). For the more hypogaeic and nocturnal species of Eciton, such as E. vagans and E. mexicanum, habitat type does not seem to affect foraging rates, with these increasing with elevation [132].

Ecological assemblages are crucial for the maintenance of ecosystem function and services, and the resilience of these is likely to be dependent on local diversity $[149,150]$. Local diversity has been shown to be strongly reduced by the destruction or disturbance of the natural environment as a result of land-use changes [151]. In tropical areas, the effect of deforestation and habitat fragmentation has led to a decrease in bird species richness [152]. The dependence of antbirds on army ant colonies make them particularly susceptible to habitat fragmentation. The reduction or disappearance of antbirds from certain forests can be explained by a decrease or absence of important resources such as the presence of army ants [34,129,153-157]. Higher species richness, as well as greater attendance of antbirds following army ants is found in continuous forests [78]. In contrast, antbirds are more prone to local extinction in small forest fragments $[155,157]$. Considering the numerous associates already reported with Eciton army ants, the disappearance of their colonies will not only have a negative effect on antbird local diversity but on the diversity of large number of species across different taxonomic groups.

\section{Eciton Army Ants as Umbrella Species in Neo-Tropical Forests}

Data on species richness and abundance is critical to prioritise the establishment of conservation areas [158]. As this information is often absent, and the effort to collect complete datasets would require long-term funded research projects, data on surrogate species - species that provide an indication of biodiversity levels in a particular area - offer an alternative solution to facilitate the establishment of conservation areas [22,159]. The use of surrogate species generally involves gathering data on their diversity and distribution to project the distribution of other less well-known taxa $[17,160]$. The use of bioindicator groups has often proved successful for identifying patterns of species at large geographical scales [160-162] but their use as predictors for species richness at smaller geographical scales, at which conservation actions take place, has been disputed [17,163,164]. An alternative approach for the delineation of conservation areas at smaller geographical scales is the use of umbrella species. Species categorised as an umbrella require large areas of habitat for their survival and, therefore, by protecting their habitat, many other species will be protected [16,165], including those that share similar ecology $[166,167]$ or those species more directly interacting with them [168]. However, the conservation of these other species is strongly dependent on the appropriate selection of the umbrella species $[169,170]$.

Vertebrates, in particular large predators, have frequently been selected as umbrella species [171]; however, an ongoing debate exists about whether or not the protection of these vertebrates can effectively conserve the habitats and ecosystems where they exist [172]. Invertebrate species have also been used as umbrella species in areas where large iconic vertebrates are absent, with butterflies being the most commonly used in terrestrial ecosystems $[168,173]$. Furthermore, increasing recognition of the central role of invertebrates, in particular insects, on the functioning of ecosystems has led to their protection as well as to implement their use for the establishment of conservation areas and management plans $[21,30,33,168]$.

It is important to highlight that the value of a particular umbrella species is underpinned by the conservation aims and that, in some instances, multiple species might need to be considered when devising conservation actions to ensure the long-term protection of local biodiversity $[168,174]$. Eciton army ants represent excellent potential umbrella 
species for the conservation of neotropical forests. A multitude of species, invertebrate and vertebrate, have already been described to be associated with Eciton colonies, with many more species yet to be reported and described [69]. Furthermore, large forested areas are needed for the long-term maintenance of their large colonies not only to guarantee a diverse leaf litter prey community but also to protect Eciton colonies from temperatures that hinder their dispersal between forest fragments $[34,39,131]$. The negative effects of deforestation, habitat fragmentation and land-use change on Eciton colonies have been reported by field-based studies [60,175] as well as genetic studies [141,142], indicating the importance of the protection of mature forests for the long-term survival of these army ants, and subsequently, for the many species depending on them. Although there are no available studies assessing any negative impact of the disappearance of Eciton colonies in non-associates, the designation of Eciton as umbrella species would also ensure the protection of other species in neotropical forests coexisting in the same areas, in particular those that require large extents of forested area for the maintenance of their populations. Therefore, conservation actions aimed to maintain the long-term persistence of army ants, either by identifying areas for protection or creation of habitat corridors to maintain or increase connectivity between Eciton colonies in fragmented forests would have positive impact on a wide range of neotropical forest species.

Despite their importance as keystone species in neotropical forests, none of the Eciton species, or in fact any other army ants, have yet been considered as umbrella species for the delimitation of conservation areas or for the monitoring of sustainable use in neotropical forests, although their significant influence in ecosystem structure, composition and functioning has been widely recognised $[34,176]$. The selection of Eciton species as umbrella species to identify priority conservation areas or monitor sustainable use could represent an effective and efficient approach for the conservation of neotropical forests and the ecosystem services that they provide. Therefore, this review calls for the consideration of Eciton army ant species in future conservation planning, design of nature reserves, and monitoring of sustainable use of forests in neotropical areas, by recognising the key role of Eciton species for the maintenance of biodiversity. To successfully achieve the long-term protection of neotropical forests, conservation actions must be led by local researchers and environmental agencies and non-governmental organisations with the participation of local communities that depend on forested areas for their livelihood [177-179].

Supplementary Materials: The following are available online at https:/ / www.mdpi.com/1424-2 818/13/3/136/s1, Table S1: Antbird species reported to attend Eciton army ant raids. Most of the reports refer to Eciton burchellii, $\mathrm{p}$ indicates species that have also been reported attending raid of E.b. parvispinum, ${ }^{\mathrm{r}}$ Eciton rapax and ${ }^{\mathrm{m}}$ E. mexicanum. The degree of specialization of antbirds is indicated as $\mathrm{Ob}$ (Obligate), $\mathrm{R}$ (Regular), and Oc (Occasional). For antbird species for which the behaviour of bivouac checking has been observed this is indicated as ${ }^{b}$. Table S2: Number of species in different arthropod families reported associated with Eciton burchellii according to Rettenmeyer et al. (2011).

Funding: This research received no external funding.

Acknowledgments: The academic editor and all the anonymous reviewers are thanked for their constructive criticism and comments on previous versions of the manuscript.

Conflicts of Interest: The authors declare no conflict of interest.

\section{References}

1. Sala, O.E.; Chapin, F.S.; Armesto, J.J.; Berlow, E.; Bloomfield, J.; Dirzo, R.; Huber-Sanwald, E.; Huenneke, L.F.; Jackson, R.B.; Kinzig, A.; et al. Global biodiversity scenarios for the year 2100. Science 2000, 287, 1770-1774. [CrossRef]

2. Fahrig, L. Effects of Habitat Fragmentation on Biodiversity. Annu. Rev. Ecol. Evol. Syst. 2003, 34, 487-515. [CrossRef]

3. Fischer, J.; Lindenmayer, D.B. Landscape modification and habitat fragmentation: A synthesis. Glob. Ecol. Biogeogr. 2007, 16, 265-280. [CrossRef]

4. de Chazal, J.; Rounsevell, M.D.A. Land-use and climate change within assessments of biodiversity change: A review. Glob. Environ. Chang. 2009, 19, 306-315. [CrossRef] 
5. Schulze, E.-D.; Mooney, H.A. Ecosystem Function of Biodiversity: A Summary; Schulze, E.-D., Mooney, H.A., Eds.; Springer: Berlin, Germany; London, UK, 1994.

6. Cardinale, B.J.; Duffy, J.E.; Gonzalez, A.; Hooper, D.U.; Perrings, C.; Venail, P.; Narwani, A.; MacE, G.M.; Tilman, D.; Wardle, D.A.; et al. Biodiversity loss and its impact on humanity. Nature 2012, 486, 59-67. [CrossRef]

7. Mitchell, M.G.E.; Bennett, E.M.; González, A. Strong and nonlinear effects of fragmentation on ecosystem service provision at multiple scales. Environ. Res. Lett. 2015, 10. [CrossRef]

8. Keenan, R.J.; Reams, G.A.; Achard, F.; de Freitas, J.V.; Grainger, A.; Lindquist, E. Dynamics of global forest area: Results from the FAO Global Forest Resources Assessment 2015. For. Ecol. Manage. 2015, 352, 9-20. [CrossRef]

9. Tyukavina, A.; Hansen, M.C.; Potapov, P.V.; Stehman, S.V.; Smith-Rodriguez, K.; Okpa, C.; Aguilar, R. Types and rates of forest disturbance in Brazilian Legal Amazon, 2000-2013. Sci. Adv. 2017, 3, 1-16. [CrossRef] [PubMed]

10. Dossa, G.G.O.; Paudel, E.; Schaefer, D.; Zhang, J.L.; Cao, K.F.; Xu, J.C.; Harrison, R.D. Quantifying the factors affecting wood decomposition across a tropical forest disturbance gradient. For. Ecol. Manage. 2020, 468. [CrossRef]

11. Alroy, J. Effects of habitat disturbance on tropical forest biodiversity. Proc. Natl. Acad. Sci. USA 2017, 114, 6056-6061. [CrossRef]

12. CBD. Secretariat of the Convention on Biological Diversity (2020). In Global Biodiversity Outlook 5; CBD: Montreal, QC, USA; ISBN 9292255398.

13. FAO; UNEP. The State of the World's Forests 2020. Forests, Biodiversity and People; FAO and UNEP: Rome, Italy, 2020.

14. Stork, N.E.; Srivastava, D.S.; Eggleton, P.; Hodda, M.; Lawson, G.; Leakey, R.R.B.; Watt, A.D. Consistency of effects of tropicalforest disturbance on species composition and richness relative to use of indicator taxa. Conserv. Biol. 2017, 31, 924-933. [CrossRef] [PubMed]

15. Gardner, T.A.; Barlow, J.; Araujo, I.S.; Ávila-Pires, T.C.; Bonaldo, A.B.; Costa, J.E.; Esposito, M.C.; Ferreira, L.V.; Hawes, J.; Hernandez, M.I.M.; et al. The cost-effectiveness of biodiversity surveys in tropical forests. Ecol. Lett. 2008, 11, 139-150. [CrossRef] [PubMed]

16. Noss, R.F. Indicators for monitoring biodiversity: A hierarchical approach. Conserv. Biol. 1990, 4, 355-364. [CrossRef]

17. Lawton, J.H.; Bignell, D.E.; Bolton, B.; Bloemers, G.F.; Eggleton, P.; Hammond, P.M.; Hodda, M.; Holt, R.D.; Larsen, T.B.; Mawdsley, N.A.; et al. Biodiversity inventories, indicator taxa and effects of habitat modification in tropical forest. Nature 1998, 391, 72-76. [CrossRef]

18. Lindenmayer, D.B.; Westgate, M.J. Are flagship, umbrella and keystone species useful surrogates to understand the consequences of landscape change? Curr. Landsc. Ecol. Reports 2020, 5, 76-84. [CrossRef]

19. Lindenmayer, D.B.; Margules, C.R.; Botkin, D.B. Indicators of biodiversity for ecologically sustainable forest management. Conserv. Biol. 2000, 14, 941-950. [CrossRef]

20. Landres, P.B.; Verner, J.; Thomas, J.W. Ecological uses of vertebrate indicator species: A critique. Conserv. Biol. 1988, 2, 316-328. [CrossRef]

21. McGeogh, M.A. The selection, testing and application of terrestrial insects as bioindicators. Biol. Rev. 1998, 73, 181-201. [CrossRef]

22. Caro, T.M.; O'Doherty, G. On the use of surrogate species in conservation biology. Conserv. Biol. 1999, 13, 805-814. [CrossRef]

23. Lewandowski, A.S.; Noss, R.F.; Parsons, D.R. The effectiveness of surrogate taxa for the representation of biodiversity. Conserv. Biol. 2010, 24, 1367-1377. [CrossRef] [PubMed]

24. Didham, R.K.; Stork, N.E.; Davis, A.J. Insects in fragmented forests: A functional approach. Trends Ecol. Evol. 1996, 11, 255-260. [CrossRef]

25. Rands, M.R.W.; Adams, W.M.; Bennun, L.; Butchart, S.H.M.; Clements, A.; Coomes, D.; Entwistle, A.; Hodge, I.; Kapos, V.; Scharlemann, J.P.W.; et al. Biodiversity conservation: Challenges beyond 2010. Science 2010, 329, 1298-1303. [CrossRef]

26. Kremen, C.; Colwell, R.K.; Erwin, T.L.; Murphy, D.D.; Noss, R.F.; Sanjayan, M.A. Terrestrial arthropod assemblages: Their use in conservation planning. Conserv. Biol. 1993, 7, 796-808. [CrossRef]

27. Hamilton, A.J.; Basset, Y.; Benke, K.K.; Grimbacher, P.S.; Miller, S.E.; Novotný, V.; Samuelson, G.A.; Stork, N.E.; Weiblen, G.D.; Yen, J.D.L. Quantifying uncertainty in estimation of tropical arthropod species richness. Am. Nat. 2010, 176, 90-95. [CrossRef]

28. Brown, K.S. Diversity, disturbance, and sustainable use of Neotropical forests: Insects as indicators for conservation monitoring. J. Insect Conserv. 1997, 1, 25-42. [CrossRef]

29. Andersen, A.N. Using ants as bioindicators: Multiscales issues in ant community ecology. Conserv. Ecol. 1997, 1. [CrossRef]

30. Andersen, A.N.; Hoffmann, B.D.; Müller, W.J.; Griffiths, A.D. Using ants as bioindicators in land management: Simplifying assessment of ant community responses. J. Appl. Ecol. 2002, 39, 8-17. [CrossRef]

31. Majer, J.D.; Orabi, G.; Bisevac, L. Ants (Hymenoptera: Formicidae) pass the bioindicator scorecard. Myrmecol. News 2007, 10, 69-76.

32. Bihn, J.H.; Gebauer, G.; Brandl, R. Loss of functional diversity of ant assemblages in secondary tropical forests. Ecology 2010, 91, 782-792. [CrossRef]

33. Groc, S.; Delabie, J.H.C.; Fernandez, F.; Petitclerc, F.; Corbara, B.; Leponce, M.; Céréghino, R.; Dejean, A. Litter-dwelling ants as bioindicators to gauge the sustainability of small arboreal monocultures embedded in the Amazonian rainforest. Ecol. Indic. 2017, 82, 43-49. [CrossRef]

34. Boswell, G.P.; Britton, N.F.; Franks, N.R. Habitat fragmentation, percolation theory and the conservation of a keystone species. Proc. R. Soc. B Biol. Sci. 1998, 265, 1921-1925. [CrossRef] 
35. Kaspari, M.; O'Donnell, S. High rates of army ant raids in the Neotropics and implications for ant colony and community structure. Evol. Ecol. Res. 2003, 5, 933-939.

36. Schneirla, T. Army Ants: A Study in Social Organization; Topoff, H.R., Ed.; Freeman, WH: San Francisco, CA, USA, 1971.

37. Rettenmeyer, C.W. Arthropods associated with neotropical army ants with a review of the behaviour of these ants (Arthropoda; Formicidae; Dorylinae). Ph.D. Thesis, The University of Kansas, Lawrence, KS, USA, 1961.

38. Gotwald, W.H., Jr. Army Ants: The Biology of Social Predation; Cornell University Press: Ithaca, NY, USA, 1995.

39. Partridge, L.W.; Britton, N.F.; Franks, N.R. Army ant population dynamics: The effects of habitat quality and reserve size on population size and time to extinction. Proc. R. Soc. B Biol. Sci. 1996, 263, 735-741. [CrossRef]

40. Secretariat of the Convention on Biological Diversity. Assessment, Conservation and Sustainable Use of Forest Biodiversity; CBD Technical Series no. 3; SCBD: Montreal, QC, USA, 2001; 130p.

41. Alonso, L.E.; Persaud, J.; Williams, A. Biodiversity Assessment Survey of the South Rupununi Savannah, Guyana. BAT Survey Report No 1.; WWF-Guianas, Guyana Office: Georgetown, Guyana, 2016.

42. Kistner, D.H. The social insects' bestiary. In Social Insects; Hermann, H.R., Ed.; Academic Press: London, UK, 1982; Volume 3 , pp. 1-244. ISBN 0323148964, 9780323148962.

43. Brady, S.G.; Fisher, B.L.; Schultz, T.R.; Ward, P.S. The rise of army ants and their relatives: Diversification of specialized predatory doryline ants. BMC Evol. Biol. 2014, 14, 1-14. [CrossRef]

44. Borowiec, M.L. Convergent evolution of the army ant syndrome and congruence in big-data phylogenetics. Syst. Biol. 2019, 68, 642-656. [CrossRef] [PubMed]

45. Gotwald, W.H., Jr. Army Ants; Academic Press, Inc.: London, UK, 1982.

46. Brady, S.G. Evolution of the army ant syndrome: The origin and long-term evolutionary stasis of a complex of behavioral and reproductive adaptations. Proc. Natl. Acad. Sci. USA 2003, 100, 6575-6579. [CrossRef] [PubMed]

47. Kronauer, D.J.C. Army Ants: Nature's Ultimate Social Hunters; Harvard University Press: Cambridge, MA, USA, 2020; ISBN 9780674241558.

48. Franks, N.R.; Hölldobler, B. Sexual competition during colony reproduction in army ants. Biol. J. Linn. Soc. 1987, 30, 229-243. [CrossRef]

49. Watkins, J.F. The Identification and Distribution of New World Army Ants; Baylor University Press: Waco, TX, USA, 1976.

50. Winston, M.E. Bridging Micro- and Macroevolution in Neotropical Army Ants; University of Chicago: Chicago, IL, USA, 2017.

51. Pérez-Espona, S.; Goodall-Copestake, W.P.; Berghoff, S.M.; Edwards, K.J.; Franks, N.R. Army imposters: Diversification of army ant-mimicking beetles with their Eciton hosts. Insectes Soc. 2018, 65, 59-75. [CrossRef]

52. Rettenmeyer, C.W. Behavioral studies of army ants. Univ. Kansas Sci. Bull. 1963, 44, $281-465$.

53. Powell, S.; Baker, B. The hidden big predators of the Neotropics: The behaviour, diet, and impact of New World army ants (Ecitoninae). Insetos Sociais Biol. Apl. 2008, 18-37.

54. Schneirla, T.C. Raiding and other outstanding ohenomena in the behavior of army ants. Proc. Natl. Acad. Sci. USA 1934, 20, 316-321. [CrossRef]

55. Hoenle, P.O.; Blüthgen, N.; Brückner, A.; Kronauer, D.J.C.; Fiala, B.; Donoso, D.A.; Smith, M.A.; Ospina Jara, B.; von Beeren, C. Species-level predation network uncovers high prey specificity in a Neotropical army ant community. Mol. Ecol. 2019, 28, 2423-2440. [CrossRef]

56. Franks, N.R.; Fletcher, C.R. Spatial patterns in army ant foraging and migration: Eciton burchelli on Barro Colorado Island, Panama. Behav. Ecol. Sociobiol. 1983, 12, 261-270. [CrossRef]

57. O'Donnell, S.; Jeanne, R.L. Notes on an army ant (Eciton burchelli) raid on a social wasp colony (Agelaia yepocapa) in Costa Rica. J. Trop. Ecol. 1990, 6, 507-509. [CrossRef]

58. Silva Vieira, S.; Höfer, H. Prey spectrum of two army ant species in central Amazonia, with special attention on their effect on spider populations. Andrias 1994, 13, 189-198.

59. Powell, S.; Franks, N.R. Ecology and the evolution of worker morphological diversity: A comparative analysis with Eciton army ants. Funct. Ecol. 2006, 20, 1105-1114. [CrossRef]

60. O'Donnell, S.; Lattke, J.; Powell, S.; Kaspari, M. Army ants in four forests: Geographic variation in raid rates and species composition. J. Anim. Ecol. 2007, 76, 580-589. [CrossRef]

61. Manubay, J.A.; Powell, S. Detection of prey odours underpins dietary specialization in a Neotropical top-predator: How army ants find their ant prey. J. Anim. Ecol. 2020, 89, 1165-1174. [CrossRef] [PubMed]

62. Hou, C.; Kaspari, M.; Vander Zanden, H.B.; Gillooly, J.F. Energetic basis of colonial living in social insects. Proc. Natl. Acad. Sci. USA 2010, 107, 3634-3638. [CrossRef]

63. Schneirla, T.; Brown, R.Z. Army-ant life and behavior under dry-season. 4. Further investigation of cyclic processess in behavioral and reproductive functions. Bull. Am. Museum Nat. Hist. 1950, 95, 263-354.

64. Franks, N.R.; Sendova-Franks, A.B. Army Ants: A Collective Intelligence: A neural network Seems an apt analogy as a colony of army ants navigates the tropical rain forest. Am. Sci. 1989, 77, 138-145.

65. Kaspari, M.; Powell, S.; Lattke, J.; O’Donnell, S. Predation and patchiness in the tropical litter: Do swarm-raiding army ants skim the cream or drain the bottle? J. Anim. Ecol. 2011, 80, 818-823. [CrossRef] [PubMed] 
66. Franks, N.R. Reproduction, foraging efficiency and worker polymorphism in army ants. In Experimental Behavioral Ecology and Sociobiology: In memoriam Karl von Frisch, 1886-1982; Hölldobler, B., Lindauer, M., Franks, N.R., Eds.; Wiley Online Library: Hoboken, NJ, USA, 1985; Volume Fortschrit, pp. 91-107. ISBN 087893460X.

67. Franks, N.R.; Bossert, W.H. The influence of swarm raiding army ants on the patchiness and diversity of a tropical leaf litter ant community. In Tropical Rain Forest: Ecology and Management. Special Publication No. 2 of the British Ecological Society; Sutton, S.L., Whitmore, T.C., Chadwick, A.C., Eds.; Blackwell: Oxford, UK, 1983; pp. 151-163.

68. Willis, E.O.; Oniki, Y. Birds and Army Ants. Annu. Rev. Ecol. Syst. 1978, 9, 243-263. [CrossRef]

69. Rettenmeyer, C.W.; Rettenmeyer, M.E.; Joseph, J.; Berghoff, S.M. The largest animal association centered on one species: The army ant Eciton burchellii and its more than 300 associates. Insectes Soc. 2011, 58, 281-292. [CrossRef]

70. Johnson, R.A. The behavior of birds attending army ant raids on Barro Colorado Island, Panama Canal Zone. Proc. Linn. Soc. New York 1954, 63-65, 41-70.

71. Brumfield, R.T.; Tello, J.G.; Cheviron, Z.A.; Carling, M.D.; Crochet, N.; Rosenberg, K.V. Phylogenetic conservatism and antiquity of a tropical specialization: Army-ant-following in the typical antbirds (Thamnophilidae). Mol. Phylogenet. Evol. 2007, 45, 1-13. [CrossRef]

72. Willis, E. the Behavior of Spotted Antbirds. Ornithol. Monogr. 1972, 10, 1-162. [CrossRef]

73. Willis, E.O. Studies of the behavior of Lunulated and Salvin's Antbirds. Condor 1968, 70, 128-148. [CrossRef]

74. Faria, C.M.A.; Rodrigues, M. Birds and army ants in a fragment of the Atlantic Forest of Brazil. J. F. Ornithol. 2009, 80, 328-335. [CrossRef]

75. Howell, T.R. Birds of a second-growth rain forest area of Nicaragua. Condor 1957, 59, 73-111. [CrossRef]

76. Driver, R.J.; DeLeon, S.; O'Donnell, S. Novel observation of a raptor, collared forest-falcon (Micrastur semitorquatus) depredating a fleeing snake at an army ant (Eciton burchellii parvispinum) raid front. Wilson J. Ornithol. 2018, 130, 792-796. [CrossRef]

77. Chaves-Campos, J.; DeWoody, J.A. The spatial distribution of avian relatives: Do obligate army-ant-following birds roost and feed near family members? Mol. Ecol. 2008, 17, 2963-2974. [CrossRef]

78. Kumar, A.; O'Donnell, S. Fragmentation and elevation effects on bird-army ant interactions in neotropical montane forest of Costa Rica. J. Trop. Ecol. 2007, 23, 581. [CrossRef]

79. Willson, S.K. Obligate army-ant following birds: A study of ecology, spatial movement patterns, and behavior in Amazonian Peru. Ornithol. Monogr. 2004, 1, 1-67. [CrossRef]

80. Swartz, M.B. Bivouac checking, a novel behavior distinguishing obligate from opportunistic species of army-ant-following birds. Condor 2001, 103, 629-633. [CrossRef]

81. Wrege, P.H.; Wikelski, M.; Mandel, J.T.; Rassweiler, T.; Couzin, I.D. Antbirds parasitizes foraging army ants. Ecology 2005, 86, 555-559. [CrossRef]

82. Von Ihering, H. Biologie und Verbreitung der brasilianischen Arten von Eciton. Entomol. Mitteilungen 1912, 1, $226-335$.

83. Bequaert, J. The predaceous enemies of ants. Auk 1923, 40, 162. [CrossRef]

84. Chesser, R.T. Comparative diets of obligate ant-following birds at a site in Northern Bolivia. Biotropica 1995, 27, 382-390. [CrossRef]

85. Rylands, A.B.; Da Cruz, M.A.O.M.; Ferrari, S.F. An association between marmosets and army ants in Brazil. J. Trop. Ecol. 1989, 5, 113-116. [CrossRef]

86. Martins, M.M. Foraging over army ants by Callithrix aurita (Primates: Callitrichidae): Seasonal occurrence? Rev. Biol. Trop. 2000, 48, 261-262.

87. Eickwort, G.C. Associations of mites with social insects. Annu. Rev. Entomol. 1990, 35, 469-488. [CrossRef]

88. Gotwald, W.H. Mites that live with army ants: A natural history of some myrmecophilous hitch-hikers, browsers, and parasites. J. Kansas Entomol. Soc. 1996, 69.

89. Elzinga, R.J. Holdfast mechanisms in certain Uropodine mites (Acarina: Uropodina). Ann. Entomol. Soc. Am. 1978, 71, 896-900. [CrossRef]

90. Elzinga, R.J.; Rettenmeyer, C.W. Seven new species of Circocylliba (Acarina: Uropodina) found on army ants. Acarologia 1975, 16, 595-611.

91. Elzinga, R.J. Two new species of Planodiscus (Acari: Uropodine), range extensions and a synonomy within the genus. Acarologia 1990, 31, 229-233.

92. Rettenmeyer, C.W. Notes on host specificity and behavior of myrmecophilous macrochelid mites. J. Kansas Entomol. Soc. 1962, 35, 358-360.

93. Berghoff, S.M.; Wurst, E.; Ebermann, E.; Sendova-Franks, A.B.; Rettenmeyer, C.W.; Franks, N.R. Symbionts of societies that fission: Mites as guests or parasites of army ants. Ecol. Entomol. 2009, 34, 684-695. [CrossRef]

94. Krantz, G.W. A Manual of Acarology, 2nd ed.; Oregon State University Book Stores: Corvallis, OR, USA, 1978.

95. Brown, B.V.; Feener, D.H. Parasitic phorid flies (Diptera: Phoridae) associated with army ants (Hymenoptera: Formicidae: Ecitoninae, Dorylinae) and their conservation biology. Biotropica 1998, 30, 482-487. [CrossRef]

96. Rettenmeyer, C.W. Observations on the biology and taxonomy of flies found over swarm raids of army ants (Diptera: Tachinidae, Conopidae). Univ. Kans. Sci. Bull. 1961, 42, 993-1066.

97. Feener, D.H.; Jacobs, L.F.; Schmidt, J.O. Specialized parasitoid attracted to a pheromone of ants. Anim. Behav. 1996, 51, 61-66. [CrossRef] 
98. Santiago-Jiménez, Q.J.; Espinosa De Los Monteros, A. Exploring myrmecophily based on the phylogenetic interrelationships of Falagonia Sharp, 1883 (Coleoptera: Staphylinidae: Aleocharinae) and allied genera. Syst. Entomol. 2016, 41, 794-807. [CrossRef]

99. Von Beeren, C.; Maruyama, M.; Kronauer, D.J.C. Community sampling and integrative taxonomy reveal new species and host specificity in the army ant-associated beetle genus Tetradonia (Coleoptera, Staphylinidae, Aleocharinae). PLoS ONE 2016, 11, 1-19. [CrossRef]

100. Seevers, C.H. A revision of the Vatesini, a tribe of neotropical myrmecophiles (Coleoptera, Staphylinidae). Rev. Bras. Entomol. 1958, 8, 181-202.

101. Akre, R.D.; Rettenmeyer, C.W. Trail-following by guests of army ants (Hymenoptera: Formicidae: Ecitonini). J. Kansas Entomol. Soc. 1968, 41, 165-174.

102. Akre, R. The behaviour of Euxenister and Pulvinister, histerid beetles associated with army ants. (Coleoptera: Histeridae; Hymenoptera: Formicidae: Dorylinae.). Pan Pacific Entomol. 1968, 44, 87-101.

103. Mann, W.M. Guests of Eciton Hamatum (Fab.) Collected by Professor W. M. Wheeler. Psyche (New York) 1925, 32, 166-177. [CrossRef]

104. Seevers, C.H. The systematics, evolution and zoogeography of staphylinid beetles associated with army ants (Coleoptera, Staphylinidae). Fieldiana Zool. 1965, 47, 137-351.

105. Akre, R.D.; Rettenmeyer, C.W. Behavior of Staphylinidae associated with army ants (Formicidae: Ecitonini). J. Kansas Entomol. Soc. 1966, 39, 745-782.

106. Kistner, D.H.; Jacobson, H.R. Cladistic analysis and taxonomic revision of the ecitophilous tribe Ecitocharini with studies of their behavior and evolution (Coleoptera, Staphylinidae, Aleocharinae). Sociobiology 1990, 17, 333-480.

107. Reichensperger, A. Ecitophilen aus Costa Rica (II), Brasilien und Peru (Staph. Hist. Clavig.). Rev. Entomol. 1933, 3, $179-194$.

108. Reichensperger, A. Beitrag zur Kenntnis der Myrmecophilenfauna Brasiliens und Costa Ricas III. (Col. Staphyl. Hist.). Arb. iiber Morphol. Taxon. Entomol. Berlin Dahlem 1935, 2, 188-218.

109. von Beeren, C.; Brückner, A.; Maruyama, M.; Burke, G.; Wieschollek, J.; Kronauer, D.J.C. Chemical and behavioral integration of army ant-associated rove beetles-A comparison between specialists and generalists. Front. Zool. 2018, 15, 1-15. [CrossRef] [PubMed]

110. Akre, R.; Torgerson, R. Behavior of Vatesus beetles associated with army ants (Coleoptera: Staphylinidae). Pan Pacific Entomol. $1969,45,269-281$.

111. Von Beeren, C.; Maruyama, M.; Kronauer, D.J.C. Cryptic diversity, high host specificity and reproductive synchronization in army ant-associated Vatesus beetles. Mol. Ecol. 2016, 25, 990-1005. [CrossRef] [PubMed]

112. Loomis, H.F. New myrmecophilous millipeds from Barro Colorado Island, Canal Zone, and Mexico. Source J. Kansas Entomol. Soc. Kansas Entomol. Soc. 1959, 32, 1-7.

113. Rettenmeyer, C.W. The behavior of millipeds found with neotropical army ants. J. Kansas Entomol. Soc. 1962, 35, $377-384$.

114. Ferrière, C. Nouveaux Diapriides du Brésil, hôtes des Eciton. Zool. Anz. 1929, 82, 156-171.

115. Borgmeier, T. Sobre alguns Diapriideos myrmecophilos, principalmente do Brasil (Hym. Diapriidae). Rev. Entomol. 1939, 10, 530-535.

116. Zikán, J.F. Myrmekophilie bei Hesperiden? Entomol. Rundschau 1929, 46, 27-28.

117. Drummond, B.A. Buttterflies associated with an army ant swarm raid in Honduras. J. Lepid. Soc. 1976, 30, $237-238$.

118. Haber, W.A. Evolutionary Ecology of Tropical Mimetic Butterflies (Lepidoptera: Ithomiiae). Ph.D. Thesis, University of Minnesota, Minneapolis, MN, USA, 1978.

119. Young, A.M. Butterflies associated with an army ant swarm raid in Honduras: The "feeding hypothesis" as an alternate explanation. J. Lepid. Soc. 1977, 31, 190.

120. Ray, T.S.; Andrews, C.C. Antbutterflies: Butterflies that follow army ants to feed on antbird droppings. Science 1980, 210, 1147-1148. [CrossRef]

121. Austin, G.T.; Brock, J.P.; Mielke, O.H.H. Ants, birds, and skippers. Trop. Lepidop. 1993, 4, 1-11.

122. Funaro, C.F.; Kronauer, D.J.C.; Moreau, C.S.; Goldman-Huertas, B.; Pierce, N.E.; Russell, J.A. Army ants harbor a host-specific clade of Entomoplasmatales bacteria. Appl. Environ. Microbiol. 2011, 77, 346-350. [CrossRef]

123. Łukasik, P.; Newton, J.A.; Sanders, J.G.; Hu, Y.; Moreau, C.S.; Kronauer, D.J.C.; O’Donnell, S.; Koga, R.; Russell, J.A. The structured diversity of specialized gut symbionts of the New World army ants. Mol. Ecol. 2017, 26, 3808-3825. [CrossRef] [PubMed]

124. Chandler, J.A.; Lang, J.; Bhatnagar, S.; Eisen, J.A.; Kopp, A. Bacterial communities of diverse Drosophila species: Ecological context of a host-microbe model system. PLoS Genet. 2011. [CrossRef] [PubMed]

125. Tiede, J.; Scherber, C.; Mutschler, J.; McMahon, K.D.; Gratton, C. Gut microbiomes of mobile predators vary with landscape context and species identity. Ecol. Evol. 2017, 7, 8545-8557. [CrossRef]

126. Paula, D.P.; Linard, B.; Crampton-Platt, A.; Srivathsan, A.; Timmermans, M.J.T.N.; Sujii, E.R.; Pires, C.S.S.; Souza, L.M.; Andow, D.A.; Vogler, A.P. Uncovering trophic interactions in arthropod predators through DNA shotgun-sequencing of gut contents. PLoS ONE 2016, 11, 1-14. [CrossRef] [PubMed]

127. Padial, J.M.; Miralles, A.; De la Riva, I.; Vences, M. The integrative future of taxonomy. Front. Zool. 2010, 7, 1-14. [CrossRef] [PubMed]

128. Laurance, W.F. Theory meets reality: How habitat fragmentation research has transcended island biogeographic theory. Biol. Conserv. 2008. [CrossRef] 
129. Offerman, H.L.; Dale, V.H.; Pearson, S.M.; Bierregaard, R.O.; O'Neill, R.V. Effects of forest fragmentation on neotropical fauna: Current research and data availability. Environ. Rev. 1995, 3, 191-211. [CrossRef]

130. Levings, S.C. Seasonal, annual, and among-site variation in the ground ant community of a deciduous tropical forest: Some causes of patchy species distributions. Ecol. Monogr. 1983. [CrossRef]

131. Meisel, J.E. Thermal ecology of the neotropical army ant Eciton burchellii. Ecol. Appl. 2006, 16, 913-922. [CrossRef]

132. Kumar, A.; Longino, J.T.; Colwell, R.K.; Donnell, S.O. Elevational patterns of diversity and abundance of eusocial paper wasps (Vespidae) in Costa Rica. Biotropica 2009, 41, 338-346. [CrossRef]

133. Willson, S.K.; Sharp, R.; Ramler, I.P.; Sen, A. Spatial movement optimization in amazonian Eciton burchellii army ants. Insectes Soc. 2011, 58, 325-334. [CrossRef]

134. Lozano-Zambrano, F.H.; Ulloa-Chacón, P.; Armbrecht, I. Ants: Species-Area relationship in tropical dry forest fragments. Neotrop. Entomol. 2009, 38, 44-54. [CrossRef] [PubMed]

135. Perfecto, I.; Vandermeer, J. Biodiversity conservation in tropical agroecosystems: A new conservation paradigm. Ann. N. Y. Acad. Sci. 2008, 1134, 173-200. [CrossRef]

136. Perfecto, I.; Snelling, R. Biodiversity and the transformation of a tropical agroecosystem: Ants in coffee plantations. Ecol. Appl. 1995, 5, 1084-1097. [CrossRef]

137. Perfecto, I.; Rice, R.A.; Greenberg, R.; van der Voort, M.E. Shade coffee: Update on a disappearing refuge for biodiversity. Bioscience 1996, 46, 598-608. [CrossRef]

138. Roberts, D.L.; Cooper, R.J.; Petit, L.J. Use of premontane moist forest and shade coffee agroecosystems by army ants in western Panama. Conserv. Biol. 2000, 14, 192-199. [CrossRef]

139. Delabie, J.H.C.; Jahyny, B.; Do Nascimento, I.C.; Mariano, C.S.F.; Lacau, S.; Campiolo, S.; Philpott, S.M.; Leponce, M. Contribution of cocoa plantations to the conservation of native ants (Insecta: Hymenoptera: Formicidae) with a special emphasis on the Atlantic Forest fauna of southern Bahia, Brazil. Biodivers. Conserv. 2007, 16, 2359-2384. [CrossRef]

140. Stouffer, P.C. Survival of the ant followers. Nat. Hist. Hist. 1998, 107, 40-43.

141. Pérez-Espona, S.; McLeod, J.E.; Franks, N.R. Landscape genetics of a top neotropical predator. Mol. Ecol. 2012, 21. [CrossRef] [PubMed]

142. Soare, T.W.; Kumar, A.; Naish, K.A.; O'Donnell, S. Genetic evidence for landscape effects on dispersal in the army ant Eciton burchellii. Mol. Ecol. 2014, 23, 96-109. [CrossRef]

143. Berghoff, S.M.; Kronauer, D.J.C.; Edwards, K.J.; Franks, N.R. Dispersal and population structure of a New World predator, the army ant Eciton burchellii. J. Evol. Biol. 2008, 21, 1125-1132. [CrossRef]

144. Jaffé, R.; Moritz, R.F.A.; Kraus, F.B. Gene flow is maintained by polyandry and male dispersal in the army ant Eciton burchellii. Popul. Ecol. 2009, 51, 227-236. [CrossRef]

145. Soare, T.W.; Kumar, A.; Naish, K.A.; O’Donnell, S. Multi-year genetic sampling indicates maternal gene flow via colony emigrations in the army ant Eciton burchellii parvispinum. Insectes Soc. 2020, 67, 155-166. [CrossRef]

146. Schneirla, T. Army-ant life and behavior under dry-season conditions with special reference to reproductive functions. II. The appearance and fate of the males. Zoologica 1948, 33, 89-112.

147. Baldridge, R.S.; Rettenmeyer, C.W.; Watkins, J.F., II. Seasonal, nocturnal and diurnal flight periodicities of Nearctic army ant males (Hymenoptera: Formicidae). J. Kansas Entomol. Soc. 1980.

148. Stouffer, P.C.; Bierregaard, R.O. Use of Amazonian forest fragments by understory insectivorous birds. Ecology 1995, 76, 2429-2445. [CrossRef]

149. Hooper, D.U.; Chapin, F.S.; Ewel, J.J.; Hector, A.; Inchausti, P.; Lavorel, S.; Lawton, J.H.; Lodge, D.M.; Loreau, M.; Naeem, S.; et al. Effects of biodiversity on ecosystem functioning: A consensus of current knowledge. Ecol. Monogr. 2005, 75, 3-35. [CrossRef]

150. Hooper, D.U.; Adair, E.C.; Cardinale, B.J.; Byrnes, J.E.K.; Hungate, B.A.; Matulich, K.L.; Gonzalez, A.; Duffy, J.E.; Gamfeldt, L.; Connor, M.I. A global synthesis reveals biodiversity loss as a major driver of ecosystem change. Nature 2012, 486, 105-108. [CrossRef]

151. Newbold, T.; Hudson, L.N.; Hill, S.L.L.; Contu, S.; Lysenko, I.; Senior, R.A.; Börger, L.; Bennett, D.J.; Choimes, A.; Collen, B.; et al. Global effects of land use on local terrestrial biodiversity. Nature 2015, 520, 45-50. [CrossRef]

152. Stratford, J.A.; Robinson, W.D. Gulliver travels to the fragmented tropics: Geographic variation in mechanisms of avian extinction. Front. Ecol. Environ. 2005, 3, 91-98. [CrossRef]

153. Lovejoy, T.E.; Bierregaard, R.O.; Rylands, A.B. Edge and other effects of isolation on Amazon forest fragments. In Conservation Biology: The Science of Scarcity and Diversity; Soulé, M.E., Ed.; Sinauer Associates: Sunderland, MA, USA, 1986; pp. $257-285$.

154. Harper, L.H. The persistence of ant-following birds in small forest fragments. Acta Amaz. 1989, 19, 249-283. [CrossRef]

155. Sekercioglu, Ç.H.; Ehrlich, P.R.; Daily, G.C.; Aygen, D.; Goehring, D.; Sandí, R.F. Disappearance of insectivorous birds from tropical forest fragments. Proc. Natl. Acad. Sci. USA 2002, 99, 263-267. [CrossRef] [PubMed]

156. Koh, L.P.; Dunn, R.R.; Sodhi, N.S.; Colwell, R.K.; Proctor, H.C.; Smith, V.S. Species coextinctions and the biodiversity crisis. Science 2004, 305, 1632-1634. [CrossRef] [PubMed]

157. Lees, A.C.; Peres, C.A. Habitat and life history determinants of antbird occurrence in variable-sized Amazonian forest fragments. Biotropica 2010, 42, 614-621. [CrossRef]

158. Margules, C.R.; Pressey, R.L.; Willias, P.H. Representing biodiversity: Data and procedures for identifying priority areas for conservation. J. Biosci. 2002, 27, 309-326. [CrossRef] [PubMed] 
159. Simberloff, D. Flagships, umbrellas, and keystones: Is single-species management passé in the landscape area? Biol. Conserv. 1998, 83, 247-257. [CrossRef]

160. Ricketts, T.H.; Dinerstein, E.; Olson, D.M.; Loucks, C. Who's where in North? Patterns of species richness and the utility of indicator taxa. Bioscience 1999, 49, 369-381. [CrossRef]

161. Pearson, D.L.; Cassola, F. World-wide species richness patterns of Tiger beetles (Coleoptera: Cicindelidae): Indicator taxon for biodiversity and conservation studies. Conserv. Biol. 1992, 6, 376-391. [CrossRef]

162. Myers, N.; Mittermeier, R.A.; Mittermeier, C.G.; da Fonseca, G.A.B.; Kent, J. Biodiversity hotspots for conservation priorities. Nature 2000, 403, 853-858. [CrossRef]

163. Reid, W.V. Biodiversity hotspots. Trends Ecol. Evol. 1998, 13, 275-280. [CrossRef]

164. Van Jaarsveld, A.S.; Freitag, S.; Chown, S.L.; Muller, C.; Koch, S.; Hull, H.; Bellamy, C.; Krüger, M.; Endrödy-Younga, S.; Mansell, M.W.; et al. Biodiversity assessment and conservation strategies. Science 1998, 279, 2106-2108. [CrossRef] [PubMed]

165. Frankel, O.H.; Soulé, M.E. Conservation and Evolution; Cambridge University Press: Cambridge, UK, 1981 ; ISBN 0521232759.

166. Martikainen, P.; Kaila, L.; Haila, Y. Threatened Beetles in White-Backed Woodpecker Habitats. Conserv. Biol. 1998, $12,293-301$. [CrossRef]

167. Swengel, S.R.; Swengel, A.B. Correlations in abundance of grassland songbirds and prairie butterflies. Biol. Conserv. 1999, 90, 1-11. [CrossRef]

168. Launer, A.E.; Murphy, D.D. Umbrella species and the conservation of habitat fragments: A case of threatened butterfly and a vanishing grassland ecosystem. Biol. Conserv. 1994, 69, 145-153. [CrossRef]

169. Berger, J. Population constraints associated with the use of Black rhinos as an umbrella species for desert herbivores. Conserv. Biol. 1997, 11, 69-78. [CrossRef]

170. Caro, T.M. Umbrella species: Critique and lessons from East Africa. Anim. Conserv. 2003, 6, 171-181. [CrossRef]

171. Zhang, C.; Zhu, R.; Sui, X.; Chen, K.; Li, B.; Chen, Y. Ecological use of vertebrate surrogate species in ecosystem conservation. Glob. Ecol. Conserv. 2020, 24, e01344. [CrossRef]

172. Sergio, F.; Caro, T.; Brown, D.; Clucas, B.; Hunter, J.; Ketchum, J.; McHugh, K.; Hiraldo, F. Top predators as conservation tools: Ecological rationale, assumptions, and efficacy. Annu. Rev. Ecol. Evol. Syst. 2008, 39, 1-19. [CrossRef]

173. Whiteman, N.K.; Sites, R.W. Aquatic insects as umbrella species for ecosystem protection in Death Valley National Park. J. Insect Conserv. 2008, 12, 499-509. [CrossRef]

174. Lambeck, R.J. Focal species: A multi-species umbrella for nature conservation. Conserv. Biol. 1997, 11, 849-856. [CrossRef]

175. Kumar, A.; O'Donnell, S. Elevation and forest clearing effects on foraging differ between surface-And subterranean-Foraging army ants (Formicidae: Ecitoninae). J. Anim. Ecol. 2009, 78, 91-97. [CrossRef] [PubMed]

176. Kaspari, M. A primer on ant ecology. In Ants: Standard Methods for Measuring and Monitoring Biodiversity; Agosti, D., Majer, J.D., Alonso, L.E., Schultz, T.R., Eds.; Smithsonian Institution Press: Washington, DC, USA, 2000; pp. 9-24.

177. Barbour, W.; Schlesinger, C. Who's the boss? Post-colonialism, ecological research and conservation management on Australian Indigenous lands. Ecol. Manag. Restor. 2012, 13, 36-41. [CrossRef]

178. Domínguez, L.; Luoma, C. Decolonising conservation policy: How colonial land and conservation ideologies persist and perpetuate indigenous injustices at the expense of the environment. Land 2020, 9, 65. [CrossRef]

179. Baker, K.; Eichhorn, M.P.; Griffiths, M. Decolonizing field ecology. Biotropica 2019, 51, 288-292. [CrossRef] 